\title{
SETTLEMENT MEASUREMENTS OPTIMISING CONSTRUCTION OF A BREAKWATER ON SOFT SOIL
}

\author{
Verhaeghe Hadewych ${ }^{1}$, Van Damme Luc ${ }^{1}$, Goemaere $\operatorname{Jan}^{1}$, Boone Evy ${ }^{2}$, De Rouck Julien ${ }^{3}$
}

\begin{abstract}
The need of an improved harbour access resulted into the construction of two new rubble mound breakwaters in Ostend, Belgium (Verhaeghe et al., 2010). Extensive soil investigation during the design phase of the breakwaters showed that the most northern part of the western breakwater is located in a zone containing a thick upper layer of soft material. To deal with the bad soil characteristics, a very strong geotextile was used to serve as a kind of armouring of the breakwater. An extensive analysis was carried out to determine how fast construction could go on, avoiding overall geotechnical failing, and to determine the settlements to be expected. During construction of the western breakwater, extensive settlement measurements were performed. This paper describes the settlement calculations performed with Plaxis2D versus the settlement measurements performed on site, leading to an optimised phasing of the construction works.
\end{abstract}

Keywords: rubble-mound breakwater; settlement measurements; settlement calculations; soft soil; geotextile

\section{INTRODUCTION - NEW OSTEND HARBOUR ENTRANCE}

Ostend is situated in the middle of the Belgian coastline. Although for many centuries Ostend was one of the most important ports at the Southern North Sea, it has a relatively small harbour. The traffic mainly consists of roll-on-roll-off and general cargo, but also some ferry and cruise traffic takes place. In order to make the harbour accessible for ships with a length up to $200 \mathrm{~m}$, important modification works at the harbour access were necessary. Studies have led to a new design of the harbour access in which the old (curved) access defined by two piers is replaced by a new access channel perpendicular to the coast line together with the construction of two new rubble mound breakwaters (Fig. 1).
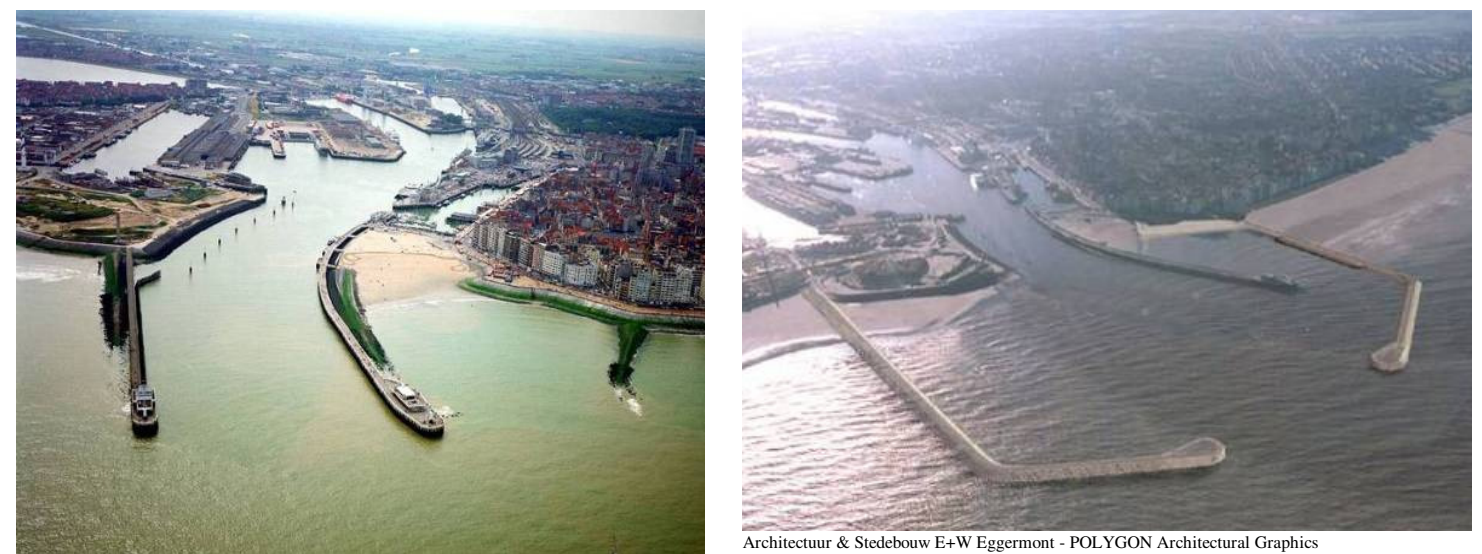

Figure 1. Old harbour access defined by two piers (left) - New harbour access with access channel perpendicular to the coast and two new breakwaters (right).

In 2007 the first construction works to improve the harbour access were started. At this moment (summer 2012) the works are almost finished. Only the last construction phase of the new breakwaters still has to be carried out, consisting of the construction of the last upper meters of the breakwaters, including the construction of a concrete walkway. Before starting this last construction phase, almost full consolidation of the soil underneath the present load has to be achieved, as cracking of the concrete walkway has to be avoided.

Detailed information on the history of the works and on the design and construction of the breakwaters can be found in Verhaeghe et al. (2010).

\footnotetext{
${ }^{1}$ Ministry of the Flemish Community, Maritime Access Division, Coastal Division, Vrijhavenstraat 3, B - 8400 Oostende, Belgium

2 Tractebel Engineering, Technum, Gistelsesteenweg 1D, B - 8400 Oostende, Belgium

${ }^{3}$ Department of Civil Engineering, Ghent University, Technologiepark 904, B - 9052, Zwijnaarde, Belgium
} 


\section{CONSTRUCTION OF THE WESTERN BREAKWATER ON SOFT SOIL USING A VERY STRONG GEOTEXTILE}

During the design phase of the breakwaters, an extensive soil investigation was performed at the location of the new breakwaters. During several campaigns a lot of CPT's (Cone Penetration Tests) and borings were performed, see Fig. 2. Further extensive laboratory testing has been carried out.

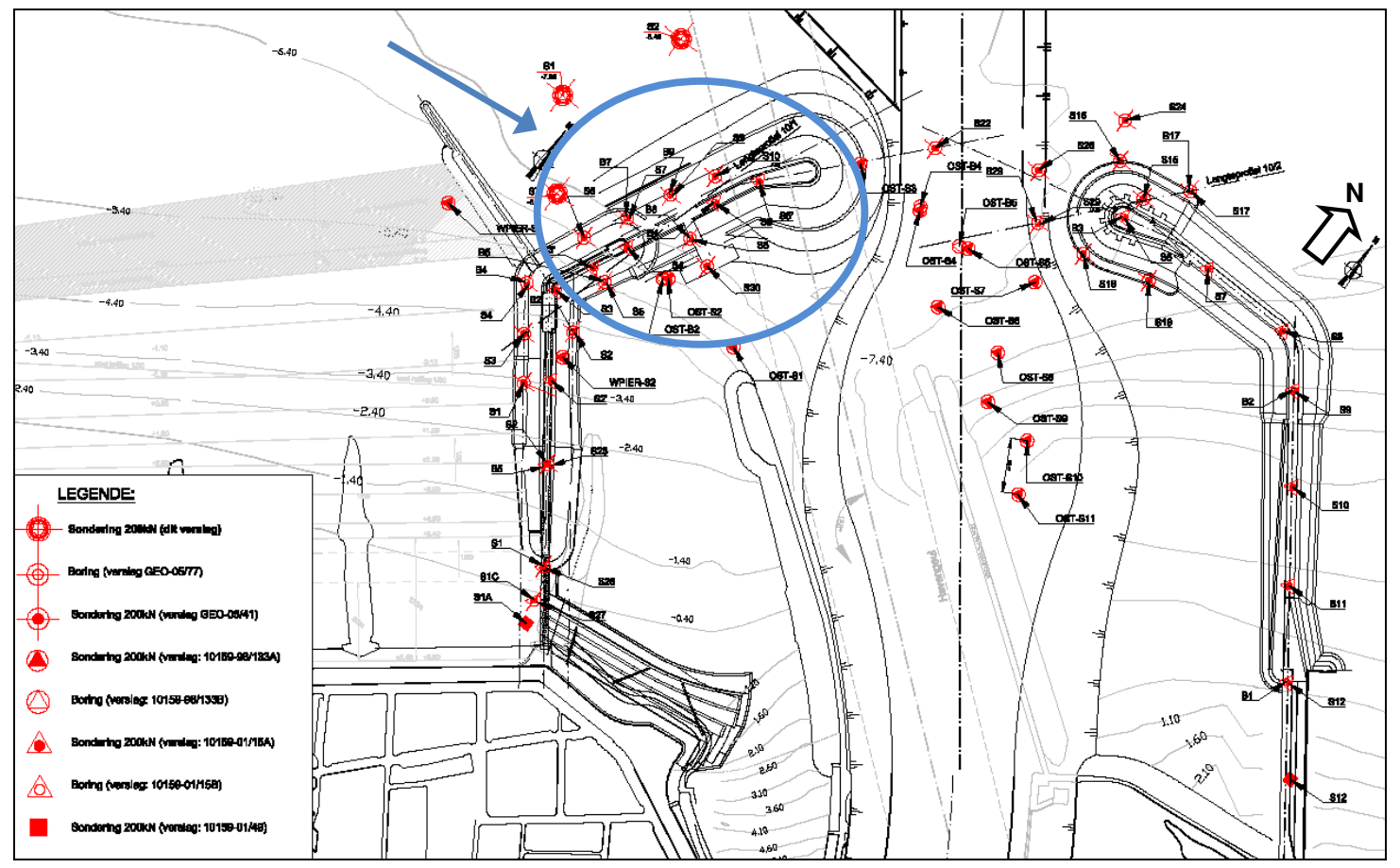

Figure 2. Overall view of location of CPT's and borings performed at the harbour of Ostend.

It was found that the soil characteristics at the location of the northern part of the western breakwater (starting from the bend to the head of the western breakwater, see Fig. 2: zone indicated with a circle) are much worse compared to the rest of the breakwaters.

Fig. 3 shows a typical CPT-result at the location of the northern part of the western breakwater. The upper layer of this zone consists of soft sandy clay and loosely packed clayey sand. Study of all CPT's and borings at the location of the northern part of the western breakwater, learned that the thickness of the soft upper layer varies quite a lot, even for CPT's close to each other. The worst CPT shows a soft layer with a thickness of approximately 10 meters.

The presence of the heterogeneous soft upper layer originates from the fact that some 25 years ago suction dredgers were used for dredging works and sand mining at that location, corresponding to

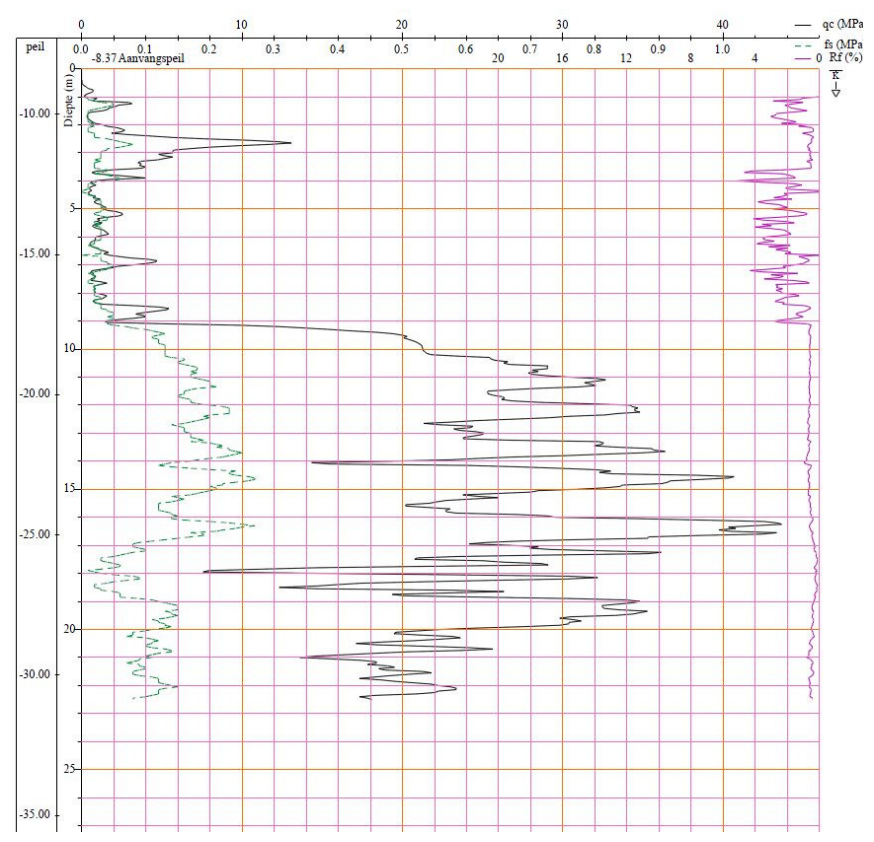

Figure 3. Typical CPT at the location of the northern part of the western breakwater. the location of the previous harbour access channel. 
An important question rose during the design phase: what is the most economical way to deal with these bad soil characteristics? Investigation learned that the most economical solution was the one in which a very strong geotextile was placed into the core of the rubble mound breakwater. The geotextile serves as armouring of the breakwater: the geotextile avoids sliding of the structure through the soft layer. The financial saving is estimated to be $\sim 8.000 .000$ EUR versus the solution to dredge and replace the soft material by sand. More information on the geotechnical design of the breakwaters can be found in De Rouck et al. (2010).

The contractor chose for a Geolon PET 1600/250 geotextile, produced by Texion (Belgium). The geotextile has a strength of $1600 \mathrm{kN} / \mathrm{m}$ (transverse direction of the breakwater) and $250 \mathrm{kN} / \mathrm{m}$ (direction of the breakwater). The seam efficiency (only seams in the direction of the breakwater) concerns $40 \%$, i.e. a seam strength of at least $100 \mathrm{kN} / \mathrm{m}$ is achieved.

The geotextile is included into the breakwater by connecting it to the willow mattresses. The willow mattresses are constructed by placing four layers of willow bundles crosswise onto the geotextile. In between the first two layers of willow bundles, loose willow branches are placed. The bundles and branches are fixed to the geotextile with ropes. The loose willow branches are necessary to avoid damage to the geotextile during ballasting the willow mattress with rock. The willow mattresses for Ostend are made on site, all work concerns handwork (Fig. 4). The willow mattresses have dimensions up to $50 \mathrm{~m}$ (length, i.e. in transverse direction of the breakwater) $\mathrm{x} 30 \mathrm{~m}$ (in the direction of the breakwater, including seams). In Fig. 5 the location of the willow mattress with the very strong geotextile (so-called 'super-geotextile') into the breakwater core is marked.

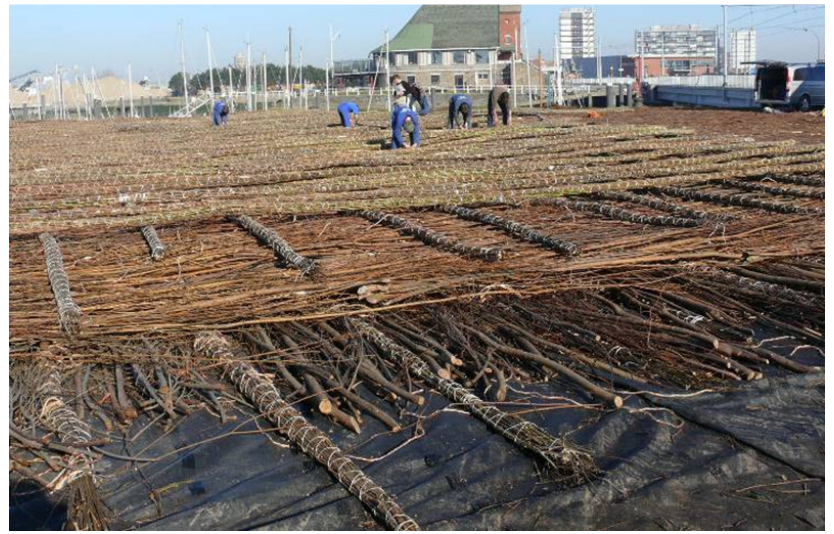

Figure 4. Construction of willow mattresses in Ostend.

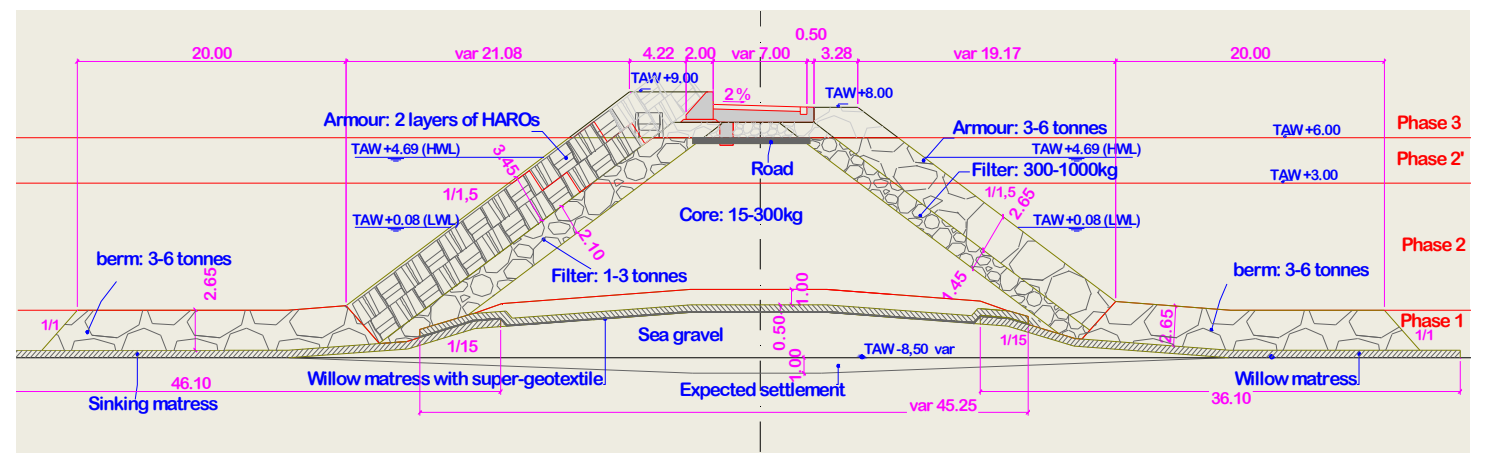

Figure 5. Typical cross-section of the northern part of the western breakwater.

The disadvantage of the method of soil strengthening using a strong geotextile to allow construction on the soft soil is that large settlements during and after construction are to be expected. The soft material settles underneath the extra load and consolidation of the soft layer takes place. It was found that to ensure stability, a phased construction method was needed.

In Fig. 5 a typical cross section of the northern part of the western breakwater is shown. It concerns a rubble mound breakwater with an armour layer consisting of a double layer of HARO's. Typically, the breakwater is constructed in four phases, i.e. phase 1, phase 2, phase 2 bis and phase 3 . The different construction phases are marked on the figure. The breakwater was constructed per phase in forward direction, i.e. from land to sea. During phase 1 the sea gravel, the willow mattresses and the berms were constructed. During phase 2 the core, the filter layers and the armour layers up to TAW $+3 \mathrm{~m}$ were constructed. During phase 2 bis, the core, the filter layers and the armour layers up to TAW $+6 \mathrm{~m}$ were 
constructed. At this moment (summer 2012) phase 2bis of the breakwater is finished. The last phase, phase 3 , consists of finishing the breakwater up to TAW $+8 \mathrm{~m}$ including the construction of a concrete walkway on it.

\section{OVERALL GEOTECHNICAL STABILITY AND SETTLEMENT CALCULATIONS WITH FEM PLAXIS2D}

\section{Modelling in Plaxis2D}

The final element method Plaxis2D is used to calculate the overall geotechnical stability of the breakwater as well as to look at the settlements of the northern part of the western breakwater to be expected. Overall geotechnical stability calculations were also performed with the software code GEOSLOPE. For more information on and results of the GEO-SLOPE calculations is referred to De Rouck et al. (2010).

In Plaxis2D the behaviour of the soil is modelled with the Mohr-Coulomb model. The safety factor SF is determined with the ' $\varphi$-c reduction'-method, i.e. the values of the angle of internal friction $\varphi$ and the cohesion $\mathrm{c}$ are reduced until local or global failing takes place:

$$
\mathrm{SF}=\tan \varphi_{\text {input }} / \tan \varphi_{\text {reduced }}=\mathrm{c}_{\text {input }} / \mathrm{c}_{\text {reduced }}
$$

Calculations are performed in ultimate limit state (ULS) to determine the safety factor. The safety factor has to be higher than 1.15 for each construction phase. Further calculations are performed in serviceability limit state (SLS) to determine settlements to be expected during and after construction.

Calculations are performed for three specific breakwater sections of the western breakwater, two of these taken at the location where CPT's are available, see Fig. 6:

- at a distance of 535m from the dike, i.e. at KP535, the section through the location of the CPT S9,

- at KP 622, the section through the location of the CPT S5', which concerns the worst CPT which was found during the soil investigation, and

- at KP 697, i.e. a section at the head of the breakwater where the breakwater has a slope angle of 1:2 instead of 1:1.5 and where the armour layer at harbour side also consists of HARO's.

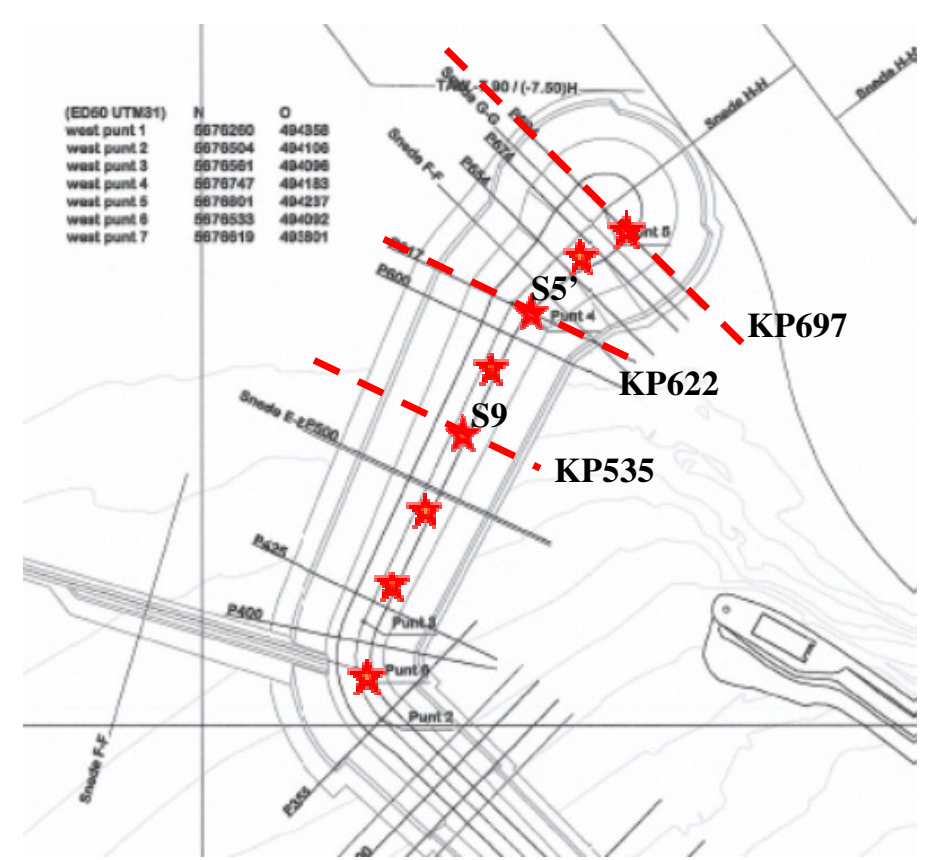

Figure 6. Breakwater sections where numerical calculations are performed (KPxxx), location of CPT's (S) and location of settlement blocks (

In this paper the results obtained at the location of KP622 are treated. 
Fig. 7 shows the cross-section at KP622 as modelled in Plaxis2D. The soft layer is situated in between TAW-19m and TAW-8.5m (bottom level). The strong geotextile is modelled with its real characteristics.

TAW -8.5m $\leftarrow$

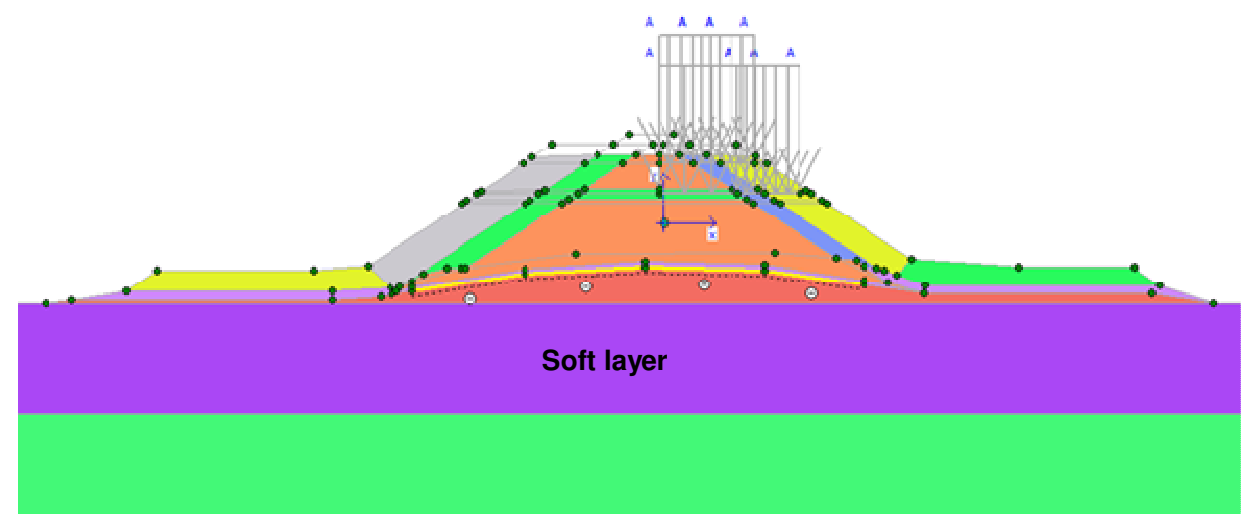

Figure 7. Cross-section at the location of KP622 modelled in Plaxis 2D.

Table 1 shows the time schedule of the construction works at the location of breakwater section KP622. The mentioned start dates of the works are the real start dates. For simplification, construction time was each time modelled to be one day.

Table 1. Time schedule of the breakwater construction at the location of KP622.

\begin{tabular}{llccc}
\hline & & $\begin{array}{c}\text { number } \\
\text { of days }\end{array}$ & START works & END works \\
\hline PHASE 1 & Sea gravel & 1 & $12 / 03 / 2010$ & $13 / 03 / 2010$ \\
& Consolidation & 82 & $13 / 03 / 2010$ & $3 / 06 / 2010$ \\
\cline { 2 - 5 } & Super-geotextile & 1 & $3 / 06 / 2010$ & $4 / 06 / 2010$ \\
& Consolidation & 48 & $4 / 06 / 2010$ & $22 / 07 / 2010$ \\
\cline { 2 - 5 } & Willow mattress sea side & 1 & $22 / 07 / 2010$ & $23 / 07 / 2010$ \\
& Consolidation & 7 & $23 / 07 / 2010$ & $30 / 07 / 2010$ \\
\cline { 2 - 5 } & Willow mattress harbour side & 1 & $30 / 07 / 2010$ & $31 / 07 / 2010$ \\
& Consolidation & 60 & $31 / 07 / 2010$ & $29 / 09 / 2010$ \\
\cline { 2 - 5 } & Berm sea side & 1 & $29 / 09 / 2010$ & $30 / 09 / 2010$ \\
& Berm harbour side & 1 & $30 / 09 / 2010$ & $1 / 10 / 2010$ \\
& Consolidation & 248 & $1 / 10 / 2010$ & $6 / 06 / 2011$ \\
\hline PHASE 2 & Construction up to TAW +2 m & 1 & $6 / 06 / 2011$ & $7 / 06 / 2011$ \\
& Consolidation & 106 & $7 / 06 / 2011$ & $21 / 09 / 2011$ \\
\cline { 2 - 5 } & Construction up to TAW +3 m & 1 & $21 / 09 / 2011$ & $22 / 09 / 2011$ \\
& Consolidation & 112 & $22 / 09 / 2011$ & $12 / 01 / 2012$ \\
\hline PHASE 2bis & Construction up to TAW +6m & 1 & $12 / 01 / 2012$ & $13 / 01 / 2012$ \\
\hline
\end{tabular}

In Table 2 the input parameters of the bottom layers for the calculations are shown.

The shear resistance characteristics $\varphi$ ' and c' are determined from laboratory testing (consolidated undrained triaxial testing with measurement of pore water pressure). The characteristics during consolidation are found by using the hydrodynamic consolidation theory of Terzaghi.

The mean E-modulus of the soft layer is determined based on compression tests on undisturbed bottom samples in the near surroundings of CPT S5'. During Plaxis 2D calculations, the E-modulus is adapted per phase as a function of the calculated real stresses, see Fig. 8 ('mean value'). 
Table 2. Input parameters of bottom layers at the location of section KP622.

\begin{tabular}{l|c|c|c|c|c|c|c|c|} 
& $\begin{array}{c}\text { Top } \\
\text { layer } \\
(\mathrm{m} \\
\mathrm{TAW})\end{array}$ & $\begin{array}{c}\text { Dry unit } \\
\text { volume } \\
\text { weight } \\
\mathrm{Vd}_{\mathrm{d}} \\
\left(\mathrm{kN} / \mathrm{m}^{3}\right)\end{array}$ & $\begin{array}{c}\text { Wet unit } \\
\text { volume } \\
\text { weight } \\
\begin{array}{l}\mathrm{V}_{\mathrm{w}} \\
\left(\mathrm{kN} / \mathrm{m}^{3}\right)\end{array}\end{array}$ & $\begin{array}{c}\text { Angle of } \\
\text { internal } \\
\text { friction } \\
\varphi^{\prime}\left({ }^{\circ}\right)\end{array}$ & $\begin{array}{c}\text { Cohesion } \\
\mathrm{C}^{\prime}(\mathrm{kPa})\end{array}$ & $\begin{array}{c}\mathrm{E}- \\
\text { modulus } \\
\left(\mathrm{kN} / \mathrm{m}^{2}\right)\end{array}$ & $\begin{array}{c}\text { Permeability } \\
\text { coefficient in } \\
\mathrm{x} \text {-direction } \\
\mathrm{K}_{\mathrm{x}}(\mathrm{m} / \mathrm{s})\end{array}$ & $\begin{array}{c}\text { Permeability } \\
\text { coefficient in } \\
\mathrm{y} \text {-direction } \\
\mathrm{k}_{\mathrm{y}}(\mathrm{m} / \mathrm{s})\end{array}$ \\
\hline $\begin{array}{l}\text { Soft layer } \\
\text { sandy clay }\end{array}$ & -8.5 & 16.5 & 16.5 & 22 & 3 & ff graph & $1 \mathrm{E}-09$ & $1 \mathrm{E}-09$ \\
\hline $\begin{array}{l}\text { Dense } \\
\text { sand }\end{array}$ & -19.0 & 18 & 20 & 35 & 0 & 100000 & $1 \mathrm{E}-06$ & $1 \mathrm{E}-06$
\end{tabular}

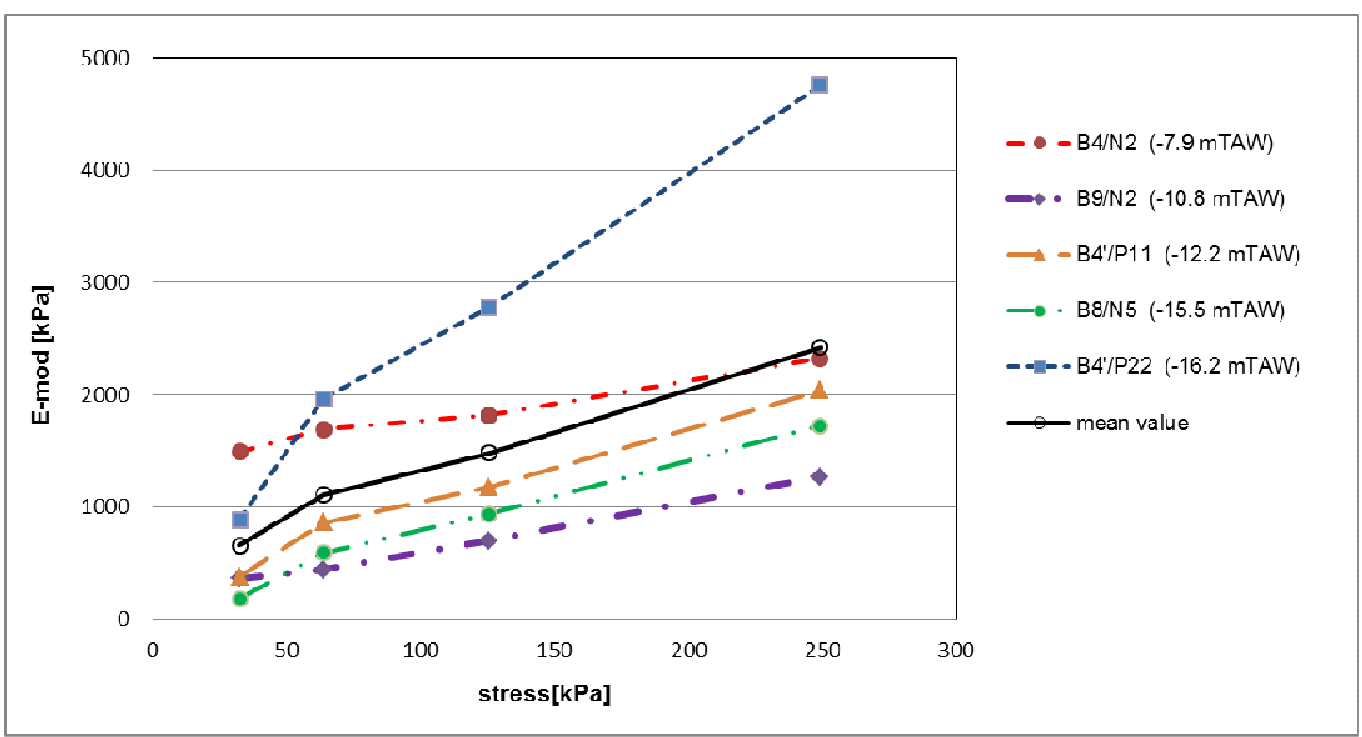

Figure 8. Mean value of the E-modulus as a function of the real stress (determined from values at different levels).

To model the geotextile in Plaxis2D, the design strength of the geotextile is calculated from the characteristic strength of it, see FGSV (1994) and DGGT (1997). The characteristic strength is reduced due to effects of creep, mechanical installation damage, environment (UV light, temperature, chemicals, ...) and an additional safety factor. Table 3 and Table 4 show the values obtained in SLS respectively ULS as a function of the age of the geotextile. At the location of S5' up to the head of the breakwater, the geotextiles are placed with an overlap of $50 \%$. The characteristic strength $F_{k}$ at these locations is calculated therefore as $1600 \mathrm{kN} / \mathrm{m}^{2 *} 1.5=2400 \mathrm{kN} / \mathrm{m}^{2}$.

Table 3. Design strength of the geotextile as a function of installation time for calculations in serviceability limit state (SLS).

\begin{tabular}{|c|c|c|c|c|c|c|c|}
\hline \multirow{2}{*}{\multicolumn{2}{|c|}{ 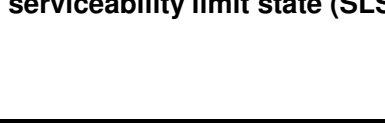 }} & \multicolumn{6}{|c|}{ SLS } \\
\hline & & 1 year & 2 year & 5 year & 10 year & 60 year & 120year \\
\hline creep & $\mathrm{A} 1[-]$ & 1,39 & 1,41 & 1,43 & 1,45 & 1,5 & 1,52 \\
\hline mechanical & A2 [-] & 1,12 & 1,12 & 1,12 & 1,12 & 1,12 & 1,12 \\
\hline no joints & A3 [-] & 1 & 1 & 1 & 1 & 1 & 1 \\
\hline environmental & A4 [-] & 1,03 & 1,03 & 1,03 & 1,03 & 1,03 & 1,03 \\
\hline \multirow[t]{3}{*}{ safety } & $g_{B}[-]$ & 1,75 & 1,75 & 1,75 & 1,75 & 1,75 & 1,75 \\
\hline & $\mathrm{F}_{\mathrm{k}}[\mathrm{kNm}]$ & 2400 & 2400 & 2400 & 2400 & 2400 & 2400 \\
\hline & $\mathrm{F}_{\mathrm{d}}[\mathrm{kNm}]$ & 855 & 843 & 831 & 820 & 793 & 782 \\
\hline
\end{tabular}


Table 4. Design strength of the geotextile as a function of installation time for calculations in ultimate limit state (ULS).

\begin{tabular}{|l|ccccccc|}
\cline { 3 - 8 } \multicolumn{1}{c|}{} & \multicolumn{7}{c|}{ ULS } \\
\hline creep & 1 year & 2 year & 5 year & 10 year & 60 year & 120year \\
mechanical & A1 [-] & 1,39 & 1,41 & 1,43 & 1,45 & 1,5 & 1,52 \\
no joints & A2 [-] & 1,12 & 1,12 & 1,12 & 1,12 & 1,12 & 1,12 \\
environmental & A3 [-] & 1 & 1 & 1 & 1 & 1 & 1 \\
safety & A4 [-] & 1,03 & 1,03 & 1,03 & 1,03 & 1,03 & 1,03 \\
& $g_{B}[-]$ & 1,4 & 1,4 & 1,4 & 1,4 & 1,4 & 1,4 \\
& $F_{k}[k N m]$ & 2400 & 2400 & 2400 & 2400 & 2400 & 2400 \\
& $F_{d}[k N m]$ & 1069 & 1054 & 1039 & 1025 & 991 & 978 \\
\hline
\end{tabular}

\section{Results - Global stability}

The safety factors obtained for the construction phases 2 and 2bis at the location of section KP622 are given in Table 5 .

$\begin{aligned} & \text { Table 5. Calculated safety factors for } \\
& \text { construction phases at KP622. }\end{aligned}$
\begin{tabular}{l|l} 
Construction phase & Safety Factor \\
\hline Phase 2 (TAW +3m) & $1.33>1.15$ \\
Phase 2bis (TAW +6m) & $1.151>1.15$
\end{tabular}

Looking at the values of the SF, it is clear that the construction phase 2 bis concerns the most critical construction phase. In Fig. 9 the sliding surface corresponding to failing for phase 2bis is shown. It can be seen that the sliding surface is not going through the geotextile but around it.

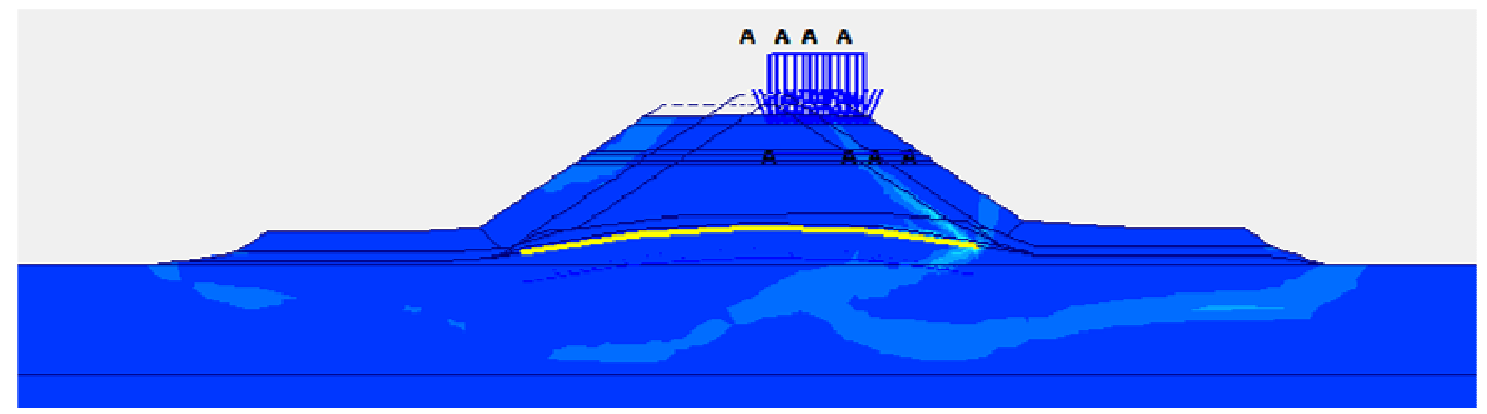

Figure 9. Sliding surface corresponding to failure after construction of phase $2 \mathrm{bis}$.

\section{Results - Settlements}

Fig. 10 shows the cross-section of the breakwater where the numerical export points are marked.

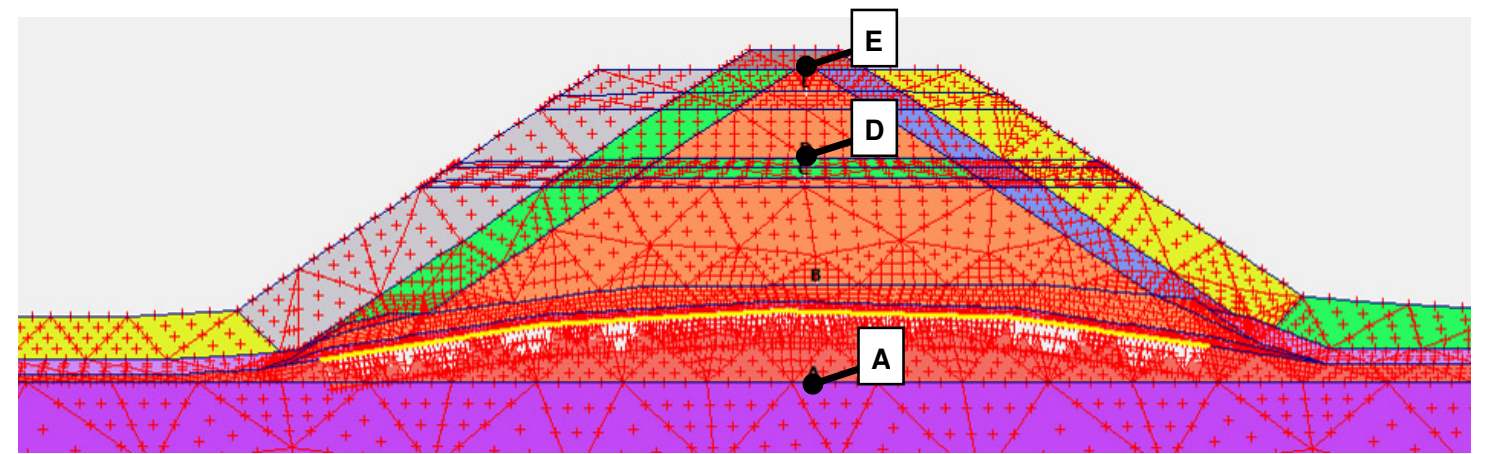

Figure 10. Cross-section of the breakwater at KP622 in Plaxis2D with indication of export points. 
Export point A refers to the upper side of the soft layer (TAW - 8.5m). Export point D refers to a level $\mathrm{TAW}+3 \mathrm{~m}$ (core), and export point $\mathrm{E}$ refers to a level TAW $+6 \mathrm{~m}$ (core).

Figure 11 shows the calculated settlements at the location of KP622 as a function of time at the different export points. The vertical parts in the settlement curve refer to an immediate settlement of the structure and soil underneath a new load (compare with the time schedule in Table 1). It can be seen from the graph that during construction up to TAW+6m (on 12/01/2012), the bottom immediately settles approximately $0.73 \mathrm{~m}-0.56 \mathrm{~m}=0.17 \mathrm{~m}$, while the structure itself immediately settles approximately $0.93 \mathrm{~m}-0.73 \mathrm{~m}=0.20 \mathrm{~m}$ (compacting of the core material).

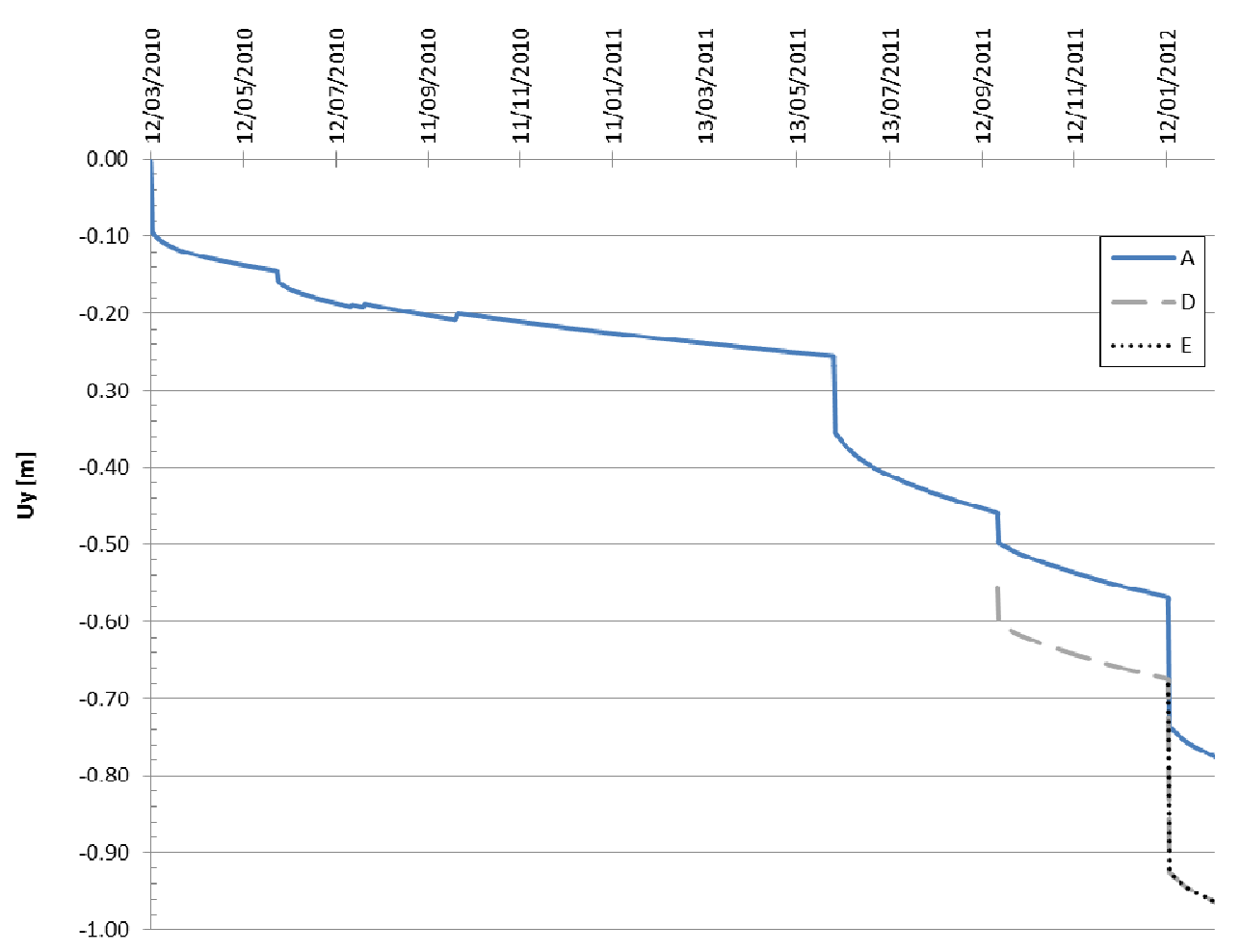

Figure 11. Calculated settlements at the location of KP622 as a function of time at different export points.

Fig. 12 shows the calculated total settlements over the whole section KP622 immediately after construction up to TAW+6m. Fig. 13 shows the calculated excess pore pressures over the whole section KP622 immediately after construction up to TAW+6m.

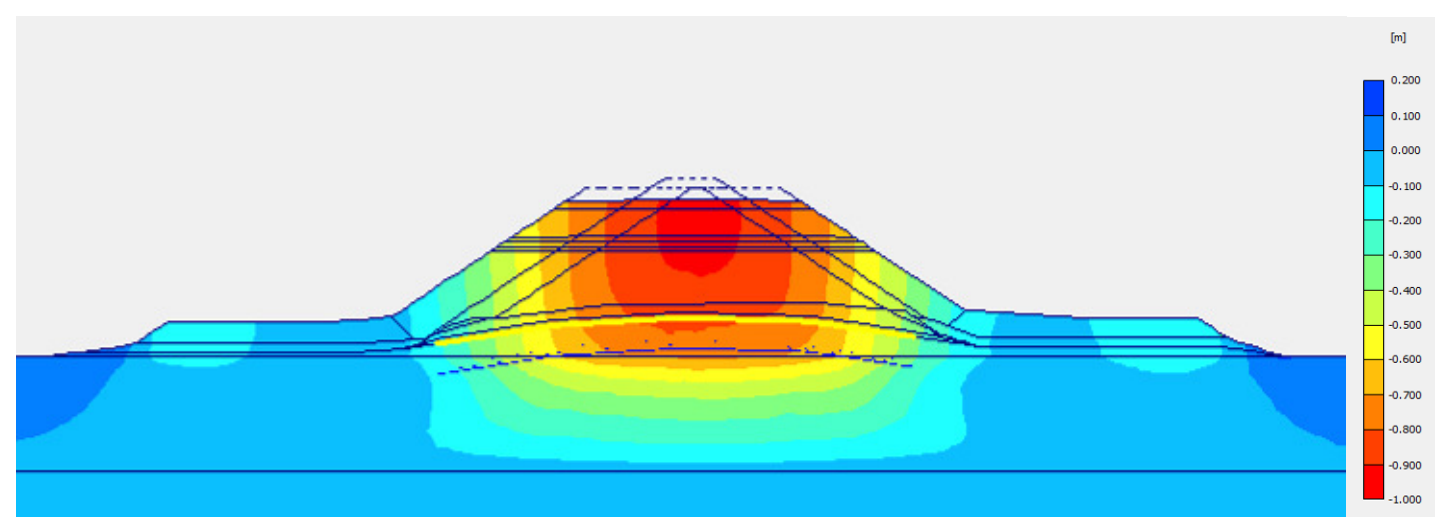

Figure 12. Calculated total settlements at section KP622 immediately after construction up tot TAW+6m. 


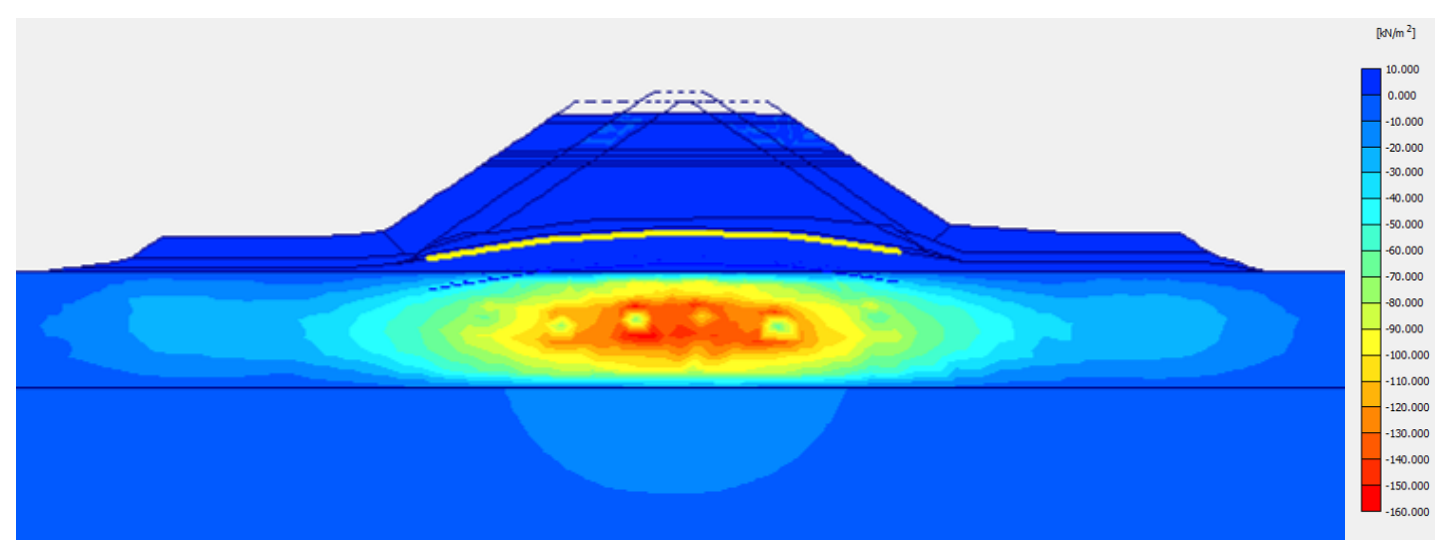

Figure 13. Calculated excess pore pressure at section KP622 immediately after construction up tot TAW+6m.

Full consolidation of the soft layer underneath the present load at the location of section KP622 is calculated to be achieved on 22/05/2026 (Fig. 14).

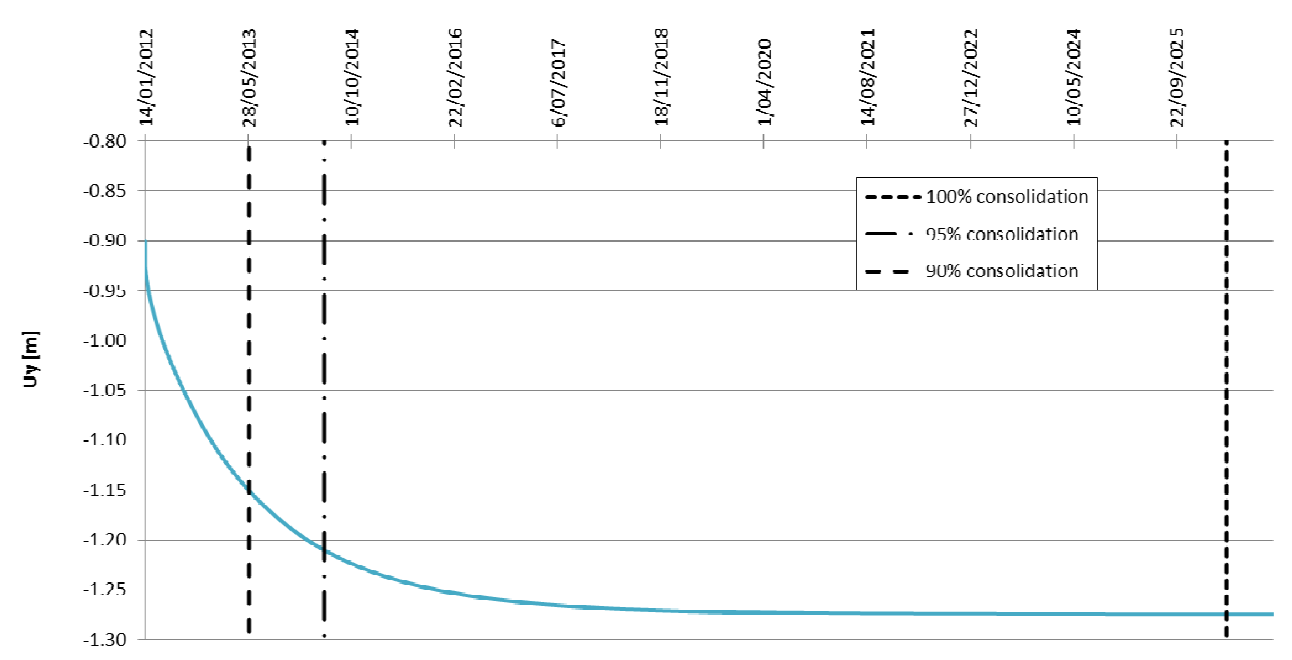

Figure 14. Settlement progress until full consolidation calculated at KP622 at a level of TAW+6m.

The corresponding maximum settlement measured at level TAW $+6 \mathrm{~m}$ is calculated to be $1.28 \mathrm{~m}$. When we define the consolidation degree as the proportion of the settlements which have already appeared to the total settlements underneath a load, Table 6 shows the dates on which consolidation degrees of $90 \%, 95 \%$ and $100 \%$ are calculated to be achieved after construction up to TAW+6m.

Table 6. Calculated consolidation degrees after construction up to TAW $+6 \mathrm{~m}$.

\begin{tabular}{c|c|c} 
Degree of consolidation & Date & $\begin{array}{c}\text { Total settlement at } \\
\text { TAW+6m }\end{array}$ \\
\hline $90 \%$ & $1 / 06 / 2013$ & $1.15 \mathrm{~m}$ \\
$95 \%$ & $1 / 06 / 2014$ & $1.21 \mathrm{~m}$ \\
$100 \%$ & $22 / 05 / 2026$ & $1.28 \mathrm{~m}$
\end{tabular}

\section{Results - tensile forces}

The calculated tensile forces in the geotextile in section KP622 after construction of phase 2 bis (TAW $+6 \mathrm{~m}$ ) are shown in Fig. 15 (SLS) and Fig. 16 (ULS). In both figures on the $\mathrm{x}$-axis the horizontal distance along the geotextile is given. The geotextiles have a length of 50 meters. The value of $x=$ zero refers to the middle of the geotextile. As expected the maximum force is each time found at that location. 


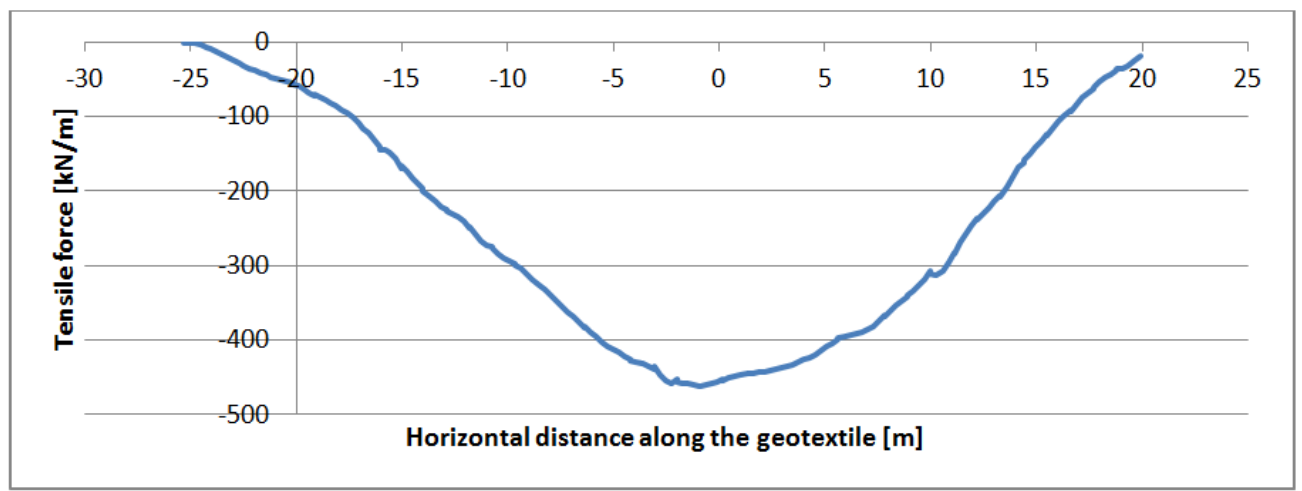

Figure 15. Calculated tensile forces in the geotextile in SLS at the location of KP622 after construction of phase 2 bis.

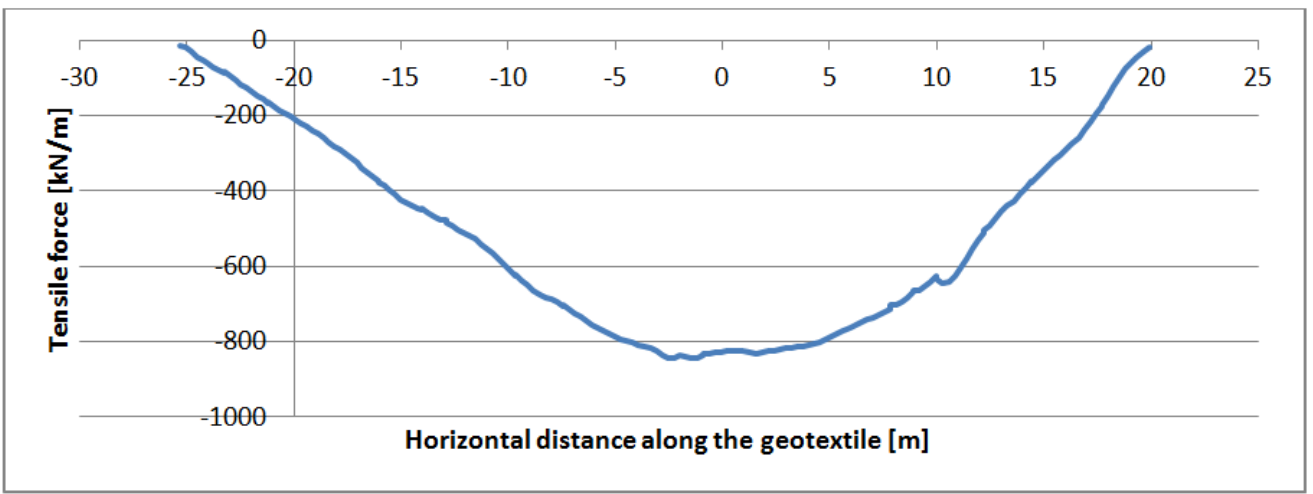

Figure 16. Calculated tensile forces in the geotextile in ULS at the location of KP622 after construction of phase 2bis.

The results in Table 7 show that the calculated maximum forces are each time smaller than the design forces, where the age of 2 years is taken into account for the geotextile. It can be concluded that the geotextile will not break after construction up to a level of TAW+6m.

\begin{tabular}{|c|c|c|c|}
\hline State & $\mathrm{F}_{\max }(\mathrm{kN} / \mathrm{m})$ & & $\mathrm{F}_{\mathrm{d}}(\mathrm{kN} / \mathrm{m})$ \\
\hline SLS & 462 & $<$ & 843 \\
\hline ULS & 845 & $<$ & 1054 \\
\hline
\end{tabular}

\section{SETTLEMENT MEASUREMENTS DURING CONSTRUCTION}

During construction of the breakwater settlement measurements are performed, first by means of piezometers (three locations) and later on by means of settlement blocks (eight locations). In Fig. 6 the locations where settlement measurements on settlement blocks have been performed are marked by little stars. The locations correspond to sections KP385, KP435, KP478, KP535, KP585, KP622, KP658 and KP697. The piezometers were placed in sections KP478, KP535 and KP622.

During the first construction phase three piezometers were installed on the willow mattresses. The piezometers were each fixed on a concrete block which was placed on the sea gravel. A typical measurement of the piezometers is shown in Fig. 17. PB5, PB7 and PB9 refer to the three piezometers. Tidal variations are filtered out of the signals. The black 'mean' lines show the increase of water column or the settlement at the location of each piezometer. The scattering of the signals around the black line originates from the waves. On the graph also the measured waves just in front of Ostend are represented. This allows explaining the 'jump' in the settlements: most probably this refers to the 
settlement of the concrete blocks itself during the storm. The non-stability of the piezometers makes it very difficult to interpret the results. Therefore, before starting construction phase 2 , the piezometers were removed and once above water level, use is made of settlement blocks.

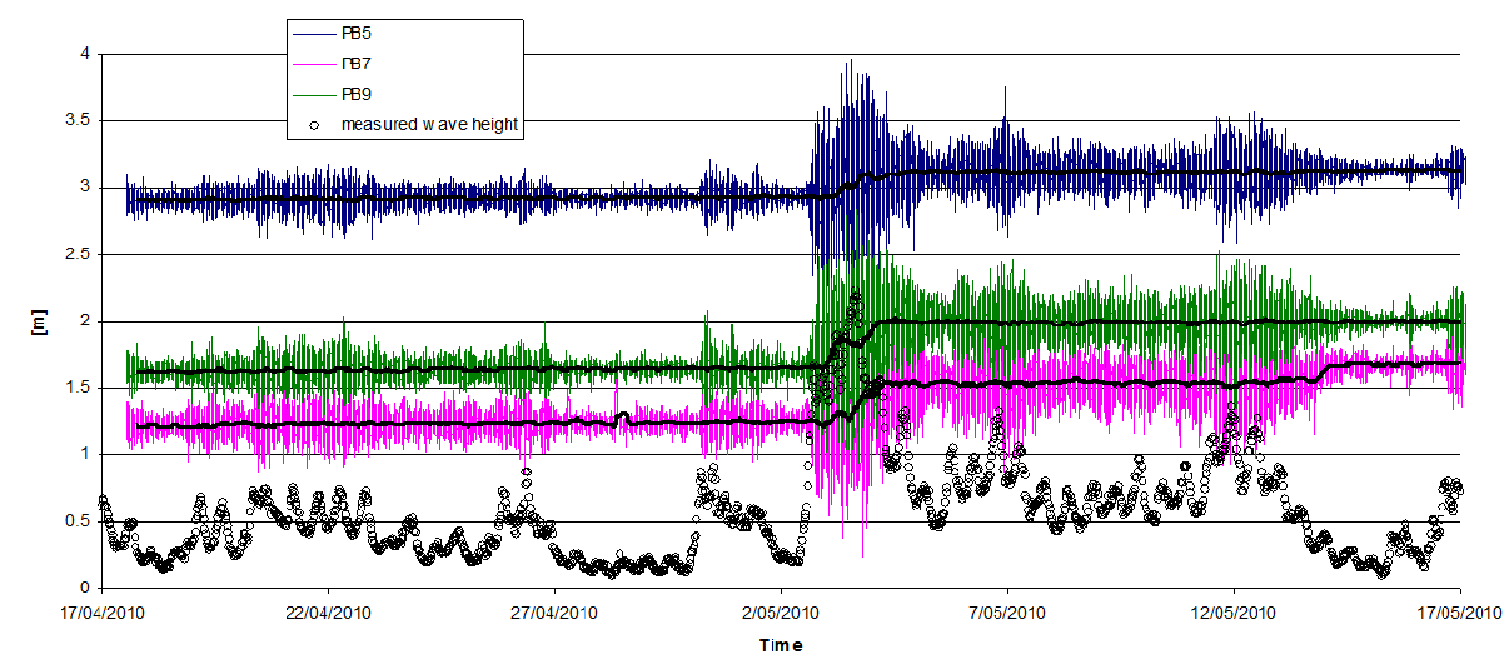

Figure 17. Settlement measurements at the northern part of the western breakwater after finishing construction phase 1.

After construction phase 2 and later on after construction phase 2 bis, eight settlement blocks with markers were placed at regular distances $(\sim 50 \mathrm{~m})$ along the crest of the western breakwater. Each time approximately $1 \mathrm{~m}^{3}$ of concrete was poured into the breakwater core, see Fig. 18. The level of the markers was measured then on a regular basis using a total station or a GPS.

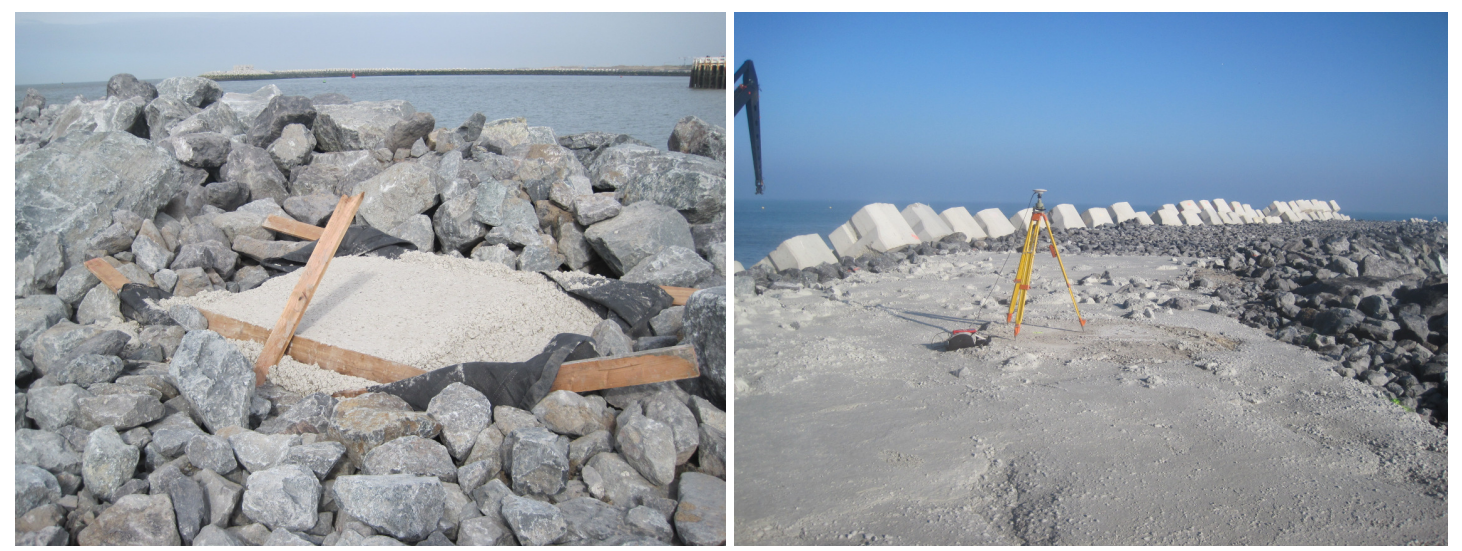

Figure 18. Pictures of settlement block poured in the breakwater (left) and set up of a total station to measure settlements (right).

Fig. 19 shows the settlement measurements performed until now (July 2012) at the different locations along the breakwater. The values as shown on the figure are absolute values, which means that the first measurement of a specific marker was set to a zero value. The first part of the graph (measurements performed in 2011) shows the settlements measured during consolidation after construction of phase 2 (TAW $+3 \mathrm{~m}$ ). The second part of the graph (measurements performed in 2012), shows the settlements measured during consolidation after construction of phase $2 \mathrm{bis}(\mathrm{TAW}+6 \mathrm{~m})$. The measurements after construction phase 2 bis were performed on newly constructed settlement blocks at the same location (but on a higher level in the breakwater). Each first measurement at level TAW+6m is set in the graph on the same settlement as the last measurement at a level TAW+3m. It is clear that the immediate settlement of the soil underneath the construction load each time could not be measured. 


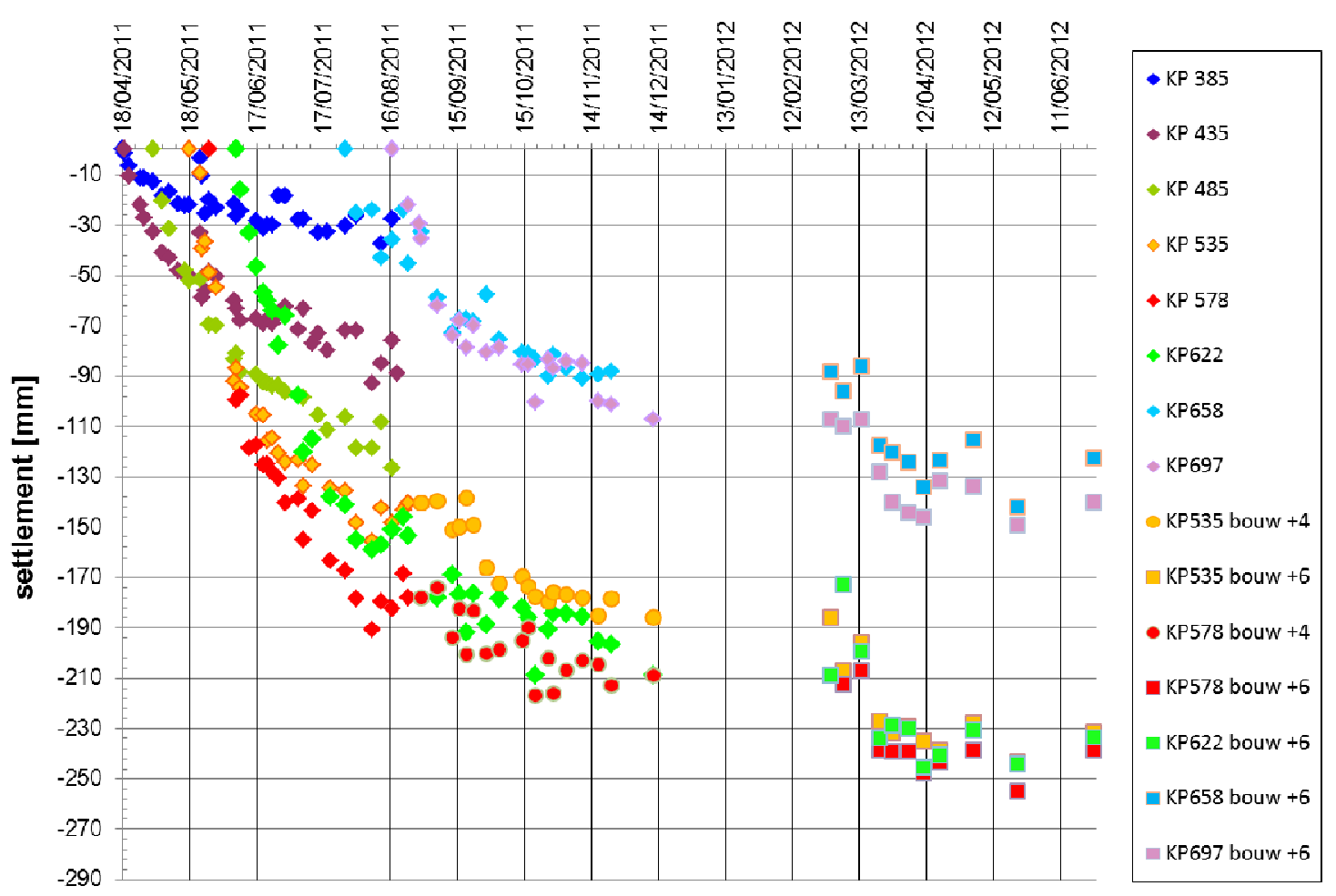

Figure 19. Absolute values of settlement measurements performed at different locations along the northern part of the western breakwater.

\section{COMPARISON - INTERPRETATION OF THE RESULTS}

As the initial settlement on site is not measured, comparison of the measurements with the calculated settlement curve is not straightforward.

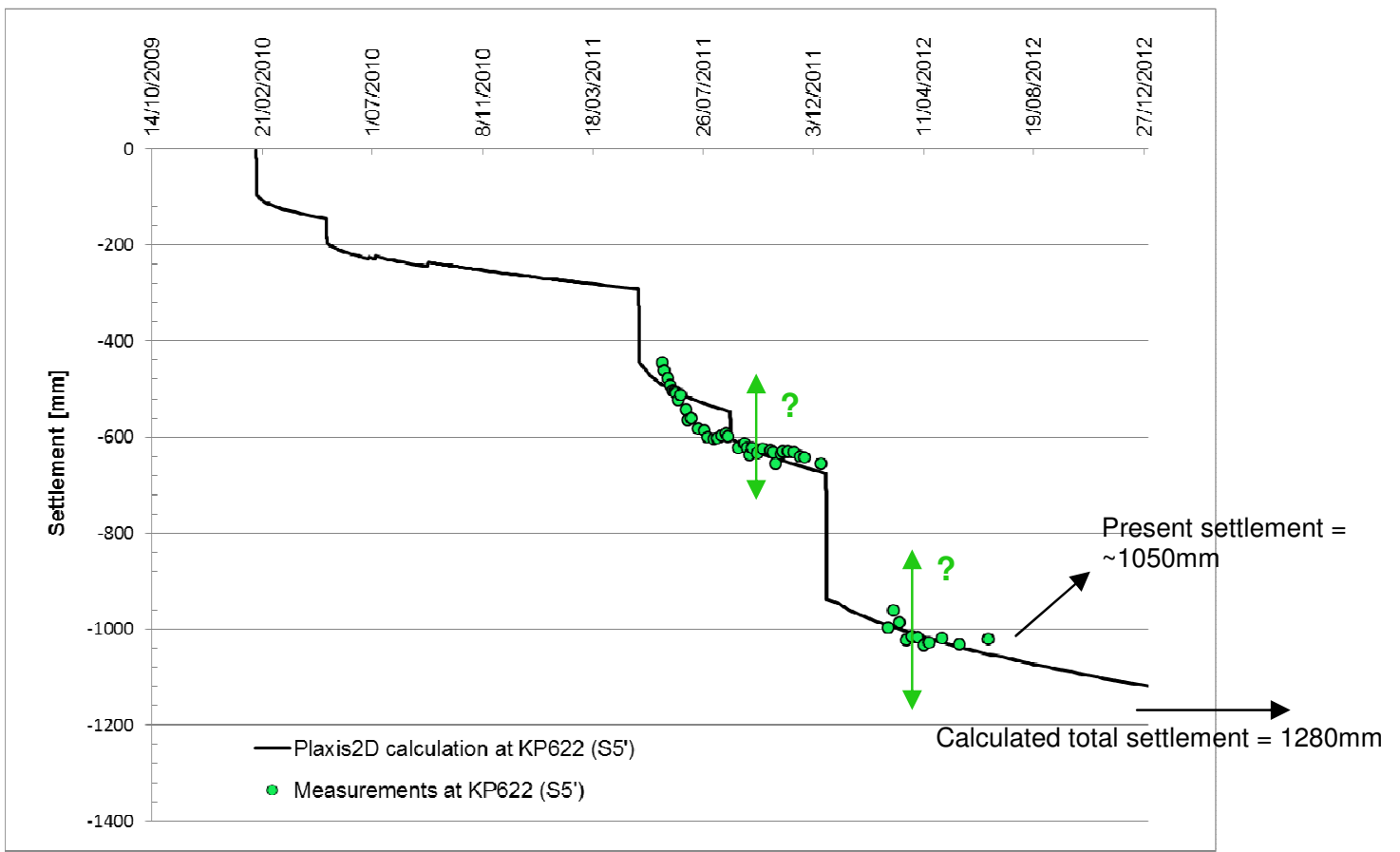

Figure 20. Best fit of settlement measurements performed at KP622 on the prediction curve calculated for the same location. 
In Fig. 20 the measurements performed at the location of section KP622 are fitted in the best way on the predicted curve for that section. For both groups of data points, i.e. measurements performed after construction of phase 2 as well as measurements performed after construction of phase 2bis, there is an uncertainty on the vertical position of the data.

Assuming the data are fitted on the correct vertical position in Fig. 20, the calculated settlements correspond quite well to the measured settlements. It can be concluded from this graph that a remaining settlement of approximately $1.28 \mathrm{~m}$ minus $1.05 \mathrm{~m}=0.23 \mathrm{~m}$ is still to be expected before full consolidation underneath the present load is achieved at KP622.

In order to deal with the problem of the missing measurement of immediate settlement of the soil, the method of Asaoka (1978) can be used. Asaoka developed an observational procedure of settlement prediction using a graphical method, see Fig. 21. Settlement measurements at fixed time intervals are plotted versus each other. The final settlement to be expected under a specific load can be determined as the intersection of the best fit through the data and the $45^{\circ}$-line. The advantage of the method is exactly that the initial settlement is not needed to be known to make an estimation of the settlement still to be expected. The longer the time intervals, the more accurate the method.

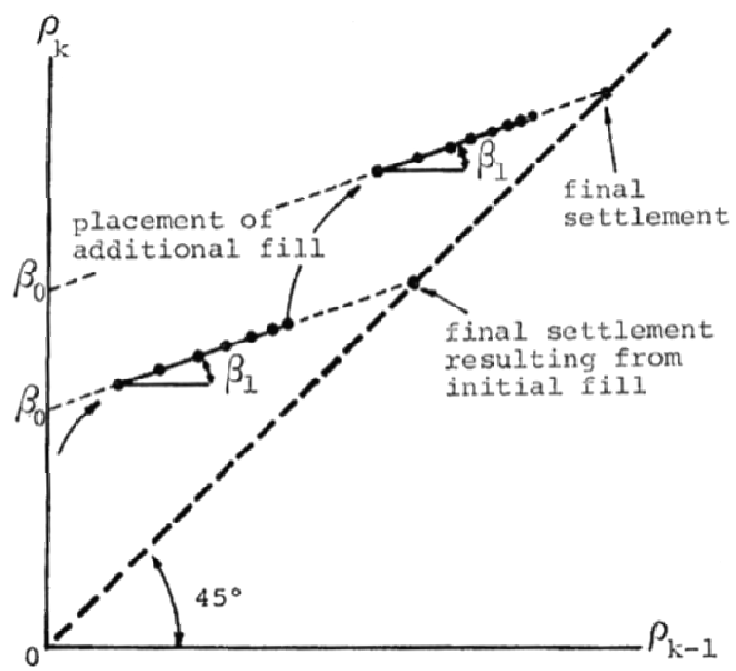

Figure 21. Graphical method of settlement prediction (Asaoka, 1978).

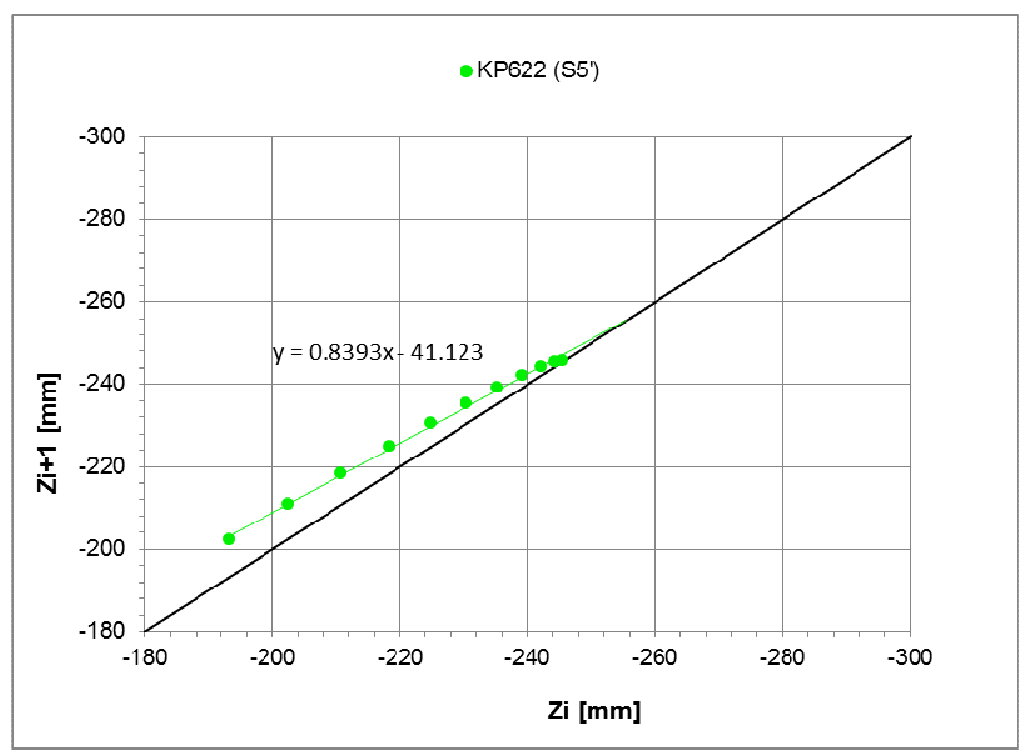

Figure 22. Graphical method of Asaoka for settlements after construction phase 2bis at section KP622. 
As the settlement measurements on the western breakwater were not performed with a fixed time interval, first a trend line is fitted through the data. Then data are picked from the trend line with a fixed time interval. In Fig. 22 the result at the location of section KP622 is shown. The settlement still to be expected at that location can be determined as the intersection with the $45^{\circ}$-line minus the settlement at this moment, i.e. $256 \mathrm{~mm}-245 \mathrm{~mm}=11 \mathrm{~mm}$.

\section{CONCLUSION}

In Ostend a breakwater has been constructed on soft soil. A lot of numerical calculations were performed to determine how fast construction could go on avoiding overall geotechnical failing. Use was made of Plaxis2D to determine the settlements corresponding with each construction phase. On site settlement measurements were performed and are still on-going. The measurements are used to validate the calculations and to decide when the final construction phase, i.e. phase 3 , including construction of the walkway on the crest, can be started.

From a 'best fit' of the settlement measurements at section KP622 on the calculated settlement curve, it can be concluded that the measurements correspond quite well to the calculations. A settlement of approximately $0.23 \mathrm{~m}$ is still expected at section KP622 until full consolidation of the soft layer underneath the present load. However, a consolidation degree of $90 \%$ will already be achieved half 2013, and a consolidation degree of $95 \%$ will already be achieved half 2014 .

The last construction phase, phase 3, is planned to start half 2013. In the meantime settlement measurements are going on and will be further compared with the calculations.

\section{REFERENCES}

Asaoka, A. 1978. Observational Procedure of Settlement Prediction. Soils and Foundations, Vol. 18, No. 4, Dec. 1978. Japanese Society of Soil Mechanics and Foundation Engineering. pp. 87-101.

De Rouck, J., Van Doorslaer, K., Goemaere, J., and H. Verhaeghe. 2010. Geotechnical design of breakwaters in Ostend on very soft soil, Proceedings of 32nd International Conference on Coastal Engineering, ASCE.

Verhaeghe, H., Van Damme, L., Goemaere, J., De Rouck, J. and Van Alboom, W. 2010. Construction of two new breakwaters at Ostend leading to an improved harbour access, Proceedings of 32nd International Conference on Coastal Engineering, ASCE.

DGGT (Deutsche Gesellschaft für Geotechnik), 1997. Empfehlungen für Bewehrungen aus Geokunststoffen (EBGEO, Recommendations for Reinforcement with Geosynthetics), ISBN 3433-01324-1.

FGSV (Forschungsgesellschaft für Straßen- und Verkehrswesen), 1994. Merkblatt für die Anwendung von Geotextilien und Geogittern im Erdbau des Straßenbaus (German guidelines for geotextiles and geogrids in soil- and road construction). 